Vivant, Elsa. 2018. "Experiencing Research-Creation in Urban Studies. Lessons from an Enquiry on the Making of Public Space." Cities 77 : 60-66.

\title{
Experiencing research-creation in urban studies Lessons from an Inquiry on the Making of Public Space
}

\author{
Elsa Vivant \\ Université Paris Est Marne la Vallée \\ Elsa.vivant@univ-paris-est.fr
}

\begin{abstract}
This paper examines collaboration between artists and social scientists in urban studies. The author was a participant in experimental research commissioned by a new cultural institution, which examined how this institution might participate in the making of a public space. In this paper she analyses the methodologies of investigation and the discussions about forms and representations, and shows the difficulties and rewards of this type of collaboration. To what extent may research based on art and social sciences, and rooted in references to the methodologies and theories of both, be a relevant and alternative way to explore, investigate and represent an urban issue?
\end{abstract}

\section{Keywords}

Art-based research, research creation, representations, urban studies, urban research, methodologies, Clichy, Montfermeil. 


\section{Experiencing research-creation in urban studies Lessons from an Inquiry on the Making of Public Space}

The relationship between artists and urban changes has been studied extensively in terms of symbolic valorisation of space in gentrification and urban regeneration processes, or economic development based on creative industries. Yet artists, through their works, can provide critical insights on the mode of production of contemporary cities, and thus afford a new understanding of spaces for different uses or even for planning purposes (Miles, 2005; Till, 2011, Molina, 2016). Some academics and practitioners have called for an alternative interpretation of the creative city, in which contact with artists might render city makers more creative (Boren \& Young, 2013). A recent study investigates several experiments in which artists collaborated with urban planners to explore a particular urban issue faced by these professionals (Arab, Ozdirlik \& Vivant, 2016). The experiments questioned urban planners' methods and practices by using alternative ways of investigating the fieldwork and representing the results. They thus activated professionals' reflexivity. For the professionals who experienced it, this collaboration with artists was an enjoyable digression in everyday professional routine, through the exploration of what Ranciere calls a new distribution of the sensible (Rancière, 2000; see also Tonnelat \& Shankland, 2016). This type of collaboration needs agreement on the means and goals. It challenges city makers' thought and artists' practices. By working with and in a world different from one's own, the artist has to reach agreement with the others on the meaning of his or her presence as an artist (Becker 1982). For instance, Tonnelat relates the case of an artist on a construction site, who twisted and modified codes while complying with conventions on the site (technical rules, legal constraints, modes of financing). All of this contributed to mutual recognition of a professional stance and respect for others (Tonnelat \& Shankland, 2016). The making of new conventions allows artists, city planners and other professionals to work together and to create a new "interpretative community" (Arab, Ozdirlik \& Vivant, 2016; Becker, 2009 ).

In the social sciences as well, some are claiming and even experimenting with new fieldwork methods inspired by art practices. Investigation in cooperation with dancers, musicians, or visual artists can transcend the linguistic barriers or emotional affects of interviews, for instance for researchers working with migrants and/or children (Armagnague, Cossée, Cossée-Cruz, Hieronimy \& Lallouette, 2017; Mekdjian, et al., 2014). In urban studies, many researchers experiment with new fieldwork methods to understand subjective and personal feelings in places and spaces (Breux, Collin \& Gringras, 2014; Grosjean \& Thibaud, 2008). Studies on perception of the urban space challenge the validity of objective knowledge to analyse this space, and stress the importance of taking the sensible and affective dimensions into account to understand the psychological, emotional and existential attachments to the urban space. Some refer explicitly to derives and psycho-geography (Radovic, 2016), or to Perec's fieldwork writings (Phillips, 2016). In fact most of these researches focused on fieldwork methods. Except for cartography (O'Rourke, 2013), the articulation of the 
investigation process and the design of the representation is rarely discussed. Yet art works and fictions may offer interesting and relevant means to tell about society and the city. Becker (2009) bids us to enlarge the repertoire of forms or media of representation of knowledge, as long as we are aware and attentive to the constraints and issues (moral, technical, financial) that may affect the making of this new representation. This paper intends to fill the gap between analysis of collaborative processes, art-based methods in social science, and the design of new representations of investigation results.

In order to analyse and appreciate more deeply what these collaborations may imply in the production of knowledge and its representation with regard to an urban issue faced by professionals, I, an urban studies researcher, ran an experiment in research collaboration with two artists (Karine Sahler geographer and stage director, and Clément Postec filmmaker) that this paper presents and discusses. My research questions were: to what extent might research based on art and social science, and rooted in references to the methodologies and theories of both, be a relevant and alternative way to explore, investigate and represent an urban issue? What lessons can be learned from it? I analyse here some of the issues we faced, during both the field investigations and the design and implementation of the representation of the results. This experience raised issues around the conceptualisation and implementation of collaborative research in urban studies. Archive analysis, interviews with stakeholders, walking through the city, and professional literature analysis all sound familiar in an academic context. They were articulated to and hybridised with artistic practices, influenced (for instance) by the theory of the emancipated spectator (Rancière, 2008), contextual art (Ardenne, 2002), uncreative writing (Goldsmith 2011), political art (Leibovici, Pihet 2011) and documentary practices in art (Baqué, 2004). These authors also inspired the design of the results. For social scientists, the question of the means of representation of data is a limited issue, even if, as Latour and Woolgar point out (2006), the process of writing knowledge into figures, tables, maps, and texts contributes to the production of knowledge itself that often ends up in 6,000-word peer-reviewed articles. Throughout the experiment we discussed the question of the means of representation to be designed. Will it be a text, a sound, a play, a visual piece, a performance, a song? Each part of the paper articulates how we relate to the investigation process and the design of the representation of the results, for working with other media raised implicit questions on the usual research media.

First, I present the context of this commissioned research and the question raised: how can the creation of a new cultural institution in a working-class suburb contribute to the making of public space? I then explain three of our main perspectives: to enlarge the audience of the research as a means to make public space; to consider the saturation of knowledge as an important issue to investigate; to consider the subjective experiences of the place of those in charge of its renewal, of those living there, of the place itself. This required that we agree on a common conventional framework connecting our diverse professional backgrounds, which was not the least of the issues we faced. Apart from collaboration with individuals from other professions (artists, social scientists), we also had to learn to negotiate with the commissioner, who would need to be equipped and informed regarding the problem at hand, that is, the 
construction of a public space. The final part of the paper will explain how the production of various prototypes throughout the experiment acts as a boundary object (Star, 2010) to test our ideas and to agree (or not) on our goals and means ${ }^{1}$. This paper is based on a reflexive analysis of the working process, the methods of investigation, the forms produced, and the relationships with the commissioners. During the whole process I noted my observations, some discussions, email exchanges ${ }^{2}$ at the different stages of the investigation, the fieldwork and the design and production of the representation of the results. Due to my position in the experiment, I was aware that there might be some bias, and therefore had this paper read and approved by the two artists I worked with.

\section{To investigate the making of a public space}

This research was commissioned by a new public cultural institution, Les Ateliers Médicis, established in Clichy-sous-bois and Montfermeil, working-class and stigmatised suburbs of north-eastern Paris. The history of this cultural institution itself deserves attention. After the 2005 Paris riots that started in these two cities, a journalist developed several projects with photographers (Collectif, 2006) and writers (Collectif, 2008). He then proposed to the two mayors the creation of an artist's residency and programme. His position in the field of journalism enabled him to present this proposal directly to the Minister of Culture who, in 2010, decided to support this project. After the presidential election turn in 2012, the project was shelved for a few years until a new Minister of Culture revived it. In 2016 an administrative frame was created, a director appointed, and a team of professionals employed. The latter were aware that the project concerned many political and ethical issues about the opportunity to create a new public cultural institution to support contemporary art creation in these suburbs, and the meaning thereof ${ }^{3}$. The definition of the project is a work in progress, at the same time as the making of its building. In this unachieved frame, the first initiative of the cultural institution was to commission a group of artists and researchers to explore and investigate how it could contribute to the making of a public space ("un espace public").

Here, we face a first issue related to the polysemy of "espace public" in French. In urban planning the term was coined in the 1960 s by a critic of modern architecture who held that public space should not be considered only as a space of flows, but also as one of social interaction (Toussaint \& Zimmermann, 2001). A public space is an arena of social interaction and regulated co-presence that requires one to learn incorporated norms of civil inattention to protect intimacy in public (Terzi \& Tonnelat, 2017). The ambiguity comes from the translation of Habermas' notion of public sphere as "espace public", which is the democratic space of debate of personal opinions and points of view. In the frame of urban issues, public space can thus be understood as public arena where planning controversies are discussed and

\footnotetext{
${ }^{1}$ Likewise, Fourmentraux, analysing the first collaboration between an artist and a computer developer for the creation of a digital work, shows that the technical and artistic dimensions are negotiated through boudary objects that serve as instruments of dialogue to solve the main dilemmas and problems of collaboration (Fourmentraux, 2008).

${ }^{2}$ As we encountered many difficulties organizing meetings, discussions were often via email.

${ }^{3}$ The project's name moreover related to Villa Médicis, a public residency for artist fellows in Rome, that is subject to criticism and controversy over the choice of artists and the conditions of their stay (Moreau, 2015).
} 
exposed, in open-air laboratories (Callon, Lascoumes, \& Barthe, 2001). This follows the pragmatic understanding of the public as "those affected by a problem that this public identifies as such, and with which they are faced and on which they can act" (Dewey, 2010).

In order to consider these various understandings of espace public (public space) and to follow Dewey, for whom the experience of the inquiry is a method to create the public and to identify and build a public problem, we investigated the making of public space as at once the public realm, the public sphere, public policies and the audience (i.e. the public) of our own work. This required first that producer and audience share aesthetic and analytic conventions and thus participate in the same interpretative community (Becker, 2009). The question of reception by the public addressed was posed differently, depending on the scientific or artistic world, but was nonetheless posed. It was even a way for the commissioner to stimulate our reflection on form: who were we catering for? What complexity did we wish to make visible, and for whom? Were the means that we implemented relevant? In a pragmatist approach, we considered that the audience did not pre-exist but instead was shaped by the process of the investigation itself. Who was concerned by the public space of the new cultural institution? Who was the audience of our research? This led us to invent a form of presentation of the results that could be reactivated, rewritten and reframed. Like the Oulipo's writing constraints (Motte, 1986, see also http://oulipo.net/), we offered data and instructions that the audience could re-investigate, re-write, re-analyse, re-interpret, and re-play, as an unending process. The production of the results reactivated the research protocol to constitute its audience and thus opened a public space of debate. We expected that the circle of those who might be concerned could be enlarged, especially towards the local inhabitants who were far from the decision process.

Finally, all these pieces of research and the artworks were presented in five chapters to a newspaper, with each chapter representing a single understanding of the public space. They were based on edited data and an open question, as an instruction to re-edit or re-investigate the issue (Fig. 1). The forms of writing we chose expressed the sense of the investigation itself: the saturation of knowledge, the diversity of perception, the running history of public investment. The newspaper was distributed by the commissioner of our research, a public cultural institution. Publishing the results of the inquiry in the form of a newspaper was the answer proposed by a graphic artist recruited to help us to format our productions. Participating as support staff (Becker, 1982), his contribution to the design of the final product proved crucial. The choice of a newspaper as a form of mediation corresponds to the idea that, for Habermas, the press is the instrument of the publicising process. As an open air laboratory (Callon, Lascoumes \& Barthes 2001), the newspaper L'ouvroir is intended to contribute to the making public of a public space. It can also be seen as a means to assume the incomplete state (due to a lack of time) of our investigation that, thanks to this protocol, never ended. 

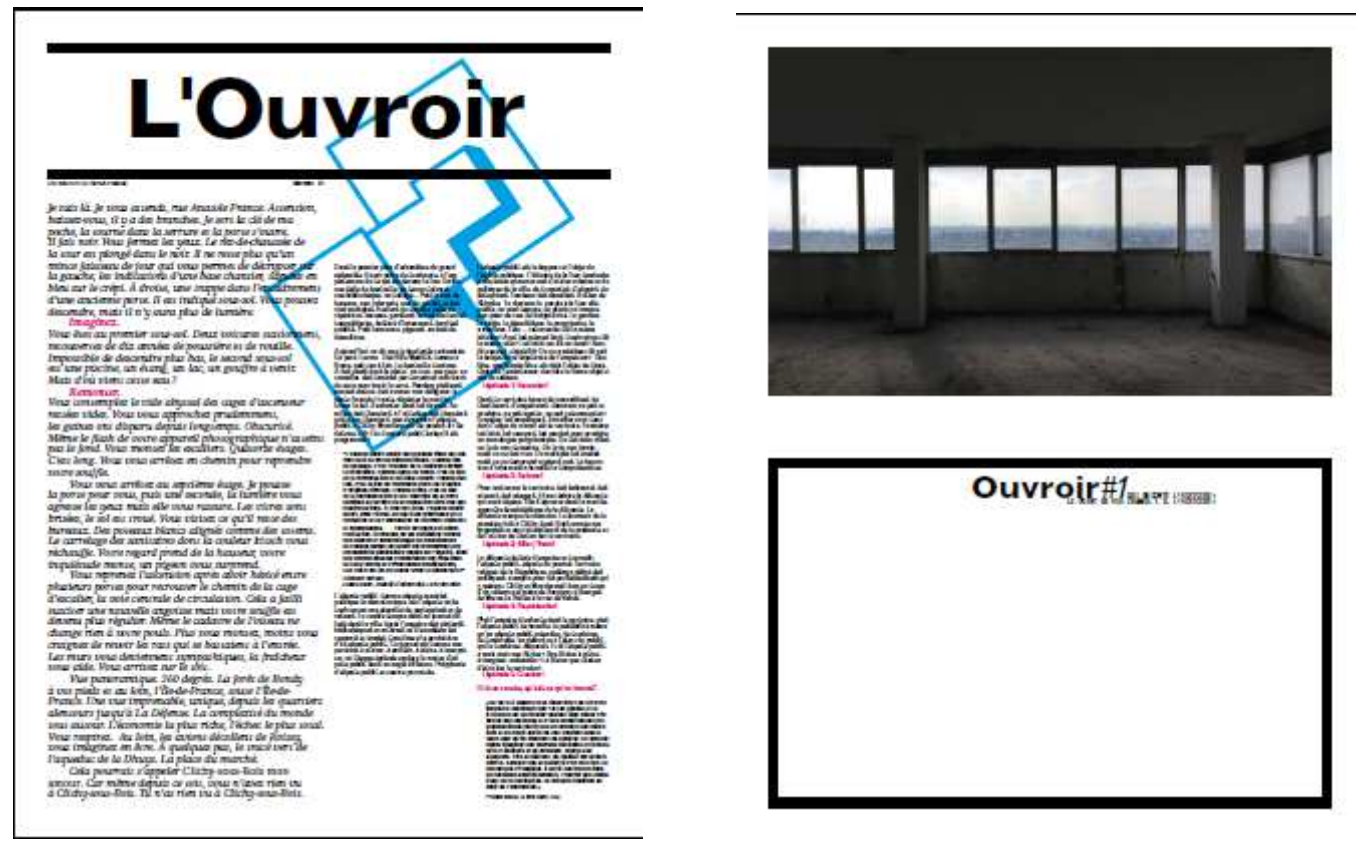

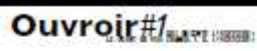

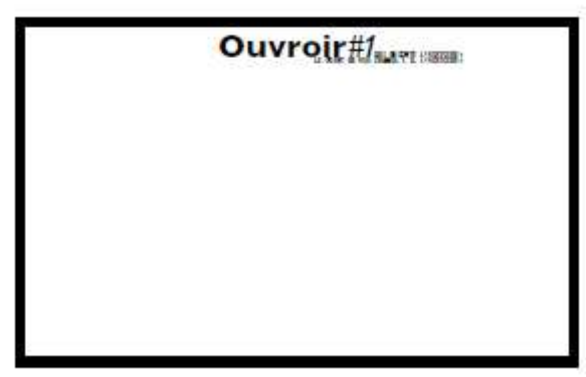

Fig. 1. L'Ouvroir: a newspaper to publish and to reactivate the investigation https://www.ateliersmedicis.fr/wp-content/uploads/2017/06/l-ouvroir.pdf

\section{To investigate a saturated field of investigation}

The two cities of Clichy and Montfermeil, located in the north-eastern suburbs of Paris, are facing major urban decay. Their fates were sealed in the 1960s and 70s, with the building of large co-ownership housing estates straddling the two cities. Planned to host middle class households, the lack of building management made them leave rapidly. A spiral of decay started. Nowadays, the apartment blocks' population is poor, low skilled and migrant. Due to the sheer size of the social and urban problems these suburbs are facing, they have been at the centre of many politicians', researchers', urban planners', architects', and journalists' interests for decades. In 2004 a large urban renewal project was launched. The plan was to demolish many co-ownership high-rise buildings that had turned into slums (Agence Nationale pour la Rénovation Urbaine, 2004). In 2015, a new national urban renewal programme (Opération de requalification des copropriétés degradées) was created specially to address Clichy's coownership issues. The mayors' demand for new public transportation to open up their towns would soon be met though the building of a new tramway and a metro station within the framework of the Grand Paris Express.

Just as Plozenet (a little village in Brittany) used to be the centre of humanities and social research in the 1960s, so Clichy and Montfermeil, as symbols of urban decay, are currently saturated with investigations (to name but a few sources: Agence Nationale pour la Rénovation Urbaine, 2004; Habouzit, 2017; Kepel, 2012; Le Garrec, 2014; Lelevrier, 2013; Atelier Parisien d'Urbanisme \& Observatoire des quartiers de gare du Grand Paris, 2015; Dilain, 2006; Lebard \& Makooi, 2015; Mitterrand, 2013; Ville Ouverte, 2015). There are so 
many reports, researches, and documentaries about this place that, at the end, it all sounds inaudible, like a brouhaha of voices, facts, and prejudices. The saturation of knowledge blurs the voices and perceptions of space. Many questions arose for us. How to understand and analyse the context in view of this contradiction: the more we read existing sources, the less we understood the field and its complexity? How to deal with all this existing (and contradictory) research material? How to represent this point of saturation and the plurality of voices and points of view?

We first organised this profusion of information into a large chronological chart to reconstruct the last fifty years of these towns' history, planning projects, and the cultural institution itself. This step was necessary to arrange the facts, identify pathways, and highlight the permanence. We considered these local facts from a broader perspective, by adding a column indicating more general information (between pop culture, international geopolitics, minority rights), and choosing items that we considered meaningful in the context studied. The making of a representation implies some transformations of data: to transcribe, select and organise the data into figures, statistics, maps, descriptions, that might be interpreted by an audience. This writing process contributes to the production of knowledge as a way to tell about society (Becker 2009, Latour \& Woolgar, 2006)). To make the effect of saturation evident and to account for the complexity, we were inspired by artists such as Franck Smith or Georges Perec, who listed facts and words. We presented this confusing saturation of data with a list of sentences (verbatim of official reports), all starting with "que" (or "that") (Fig.2). Did we mean: "the fact is that" "we know that" "we say that" "we presume that"? Are these facts or suppositions? We let the reader decide while we created a poem that sounded like spoken words. In our assay of uncreative writing (Goldsmith, 2011), the process of writing consists in copying, pasting, rephrasing and editing a large amount of verbatim in a form that produces a significant effect of saturation. This form is influenced by the analysis of the contemporary by Lionel Ruffel (Ruffel, 2016), who considers the turn of "contemporary" into a substantive that celebrates the plurality of voices and worlds (which he calls a brouhaha) in a regime of publication as a new condition of contemporary humans. Our discussion does not revolve around the selection of the data or their order (that occurs more by chance, without discussion); it focuses on the choice of enuniciation and presentation of facts. The discussion sways between what "sounds" good and what "makes" sense. While the former dislikes the repetition of "que", the scansion that "sounds wrong", in the latter the mode of enuniciation introduces doubt between facts and prejudices. Without the "que" (that), the text changes meaning and becomes an string of affirmations. Like a slam, the "que" creates a feeling of saturation that is pleasant. An intermediate term was made by introducing the text with an indication of "some facts, fictions, prejudices, dreams...." . 


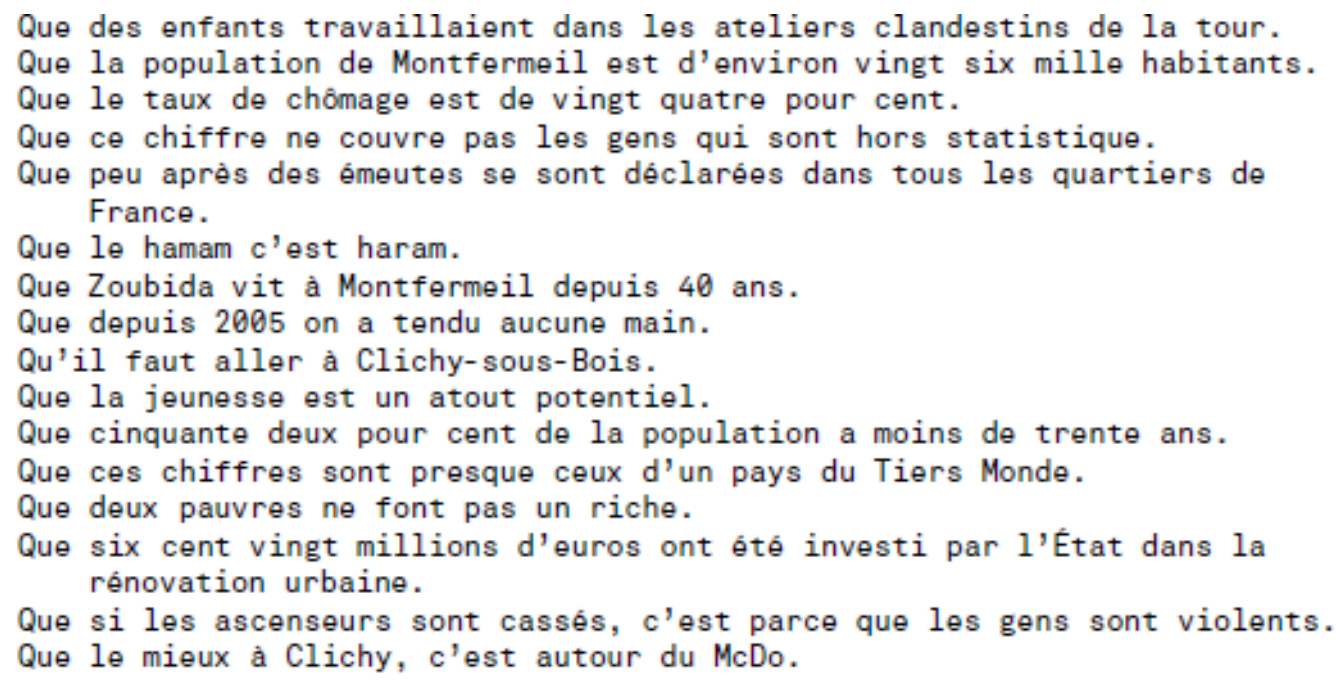

Fig. 2. A poem of saturated knowledge. Excerpt of L'ouvroir

\section{To explore the subjectivities}

In view of the saturation of (objective) knowledge, we turned to a more subjective view or perception of public space. In order to share the incomprehension gripping us when faced with such complexity, we experimented with another way of telling the story of these towns and the numerous public initiatives concerning them. Based on a large archive analysis and interviews with professionals in charge of urban renewal, we reconstructed the history of public interventions on one particular building: the Tour Utrillo. For years this used to be an empty office building at the centre of every urban renewal programme, with unsatisfying effects. Moreover, this building was supposed to host Les Ateliers Medicis, but will be eventually destroyed to give way to a new metro station. The Tour appears as a metonomy of public action in the area, with her fantasies and ghosts. In order to give the floor to an alternative voice about urban renewal, we wrote this history from the building's point of view, from her personal subjective perception. Thus, instead of writing an analysis of public policies, we wrote the autobiography of the Tour. For instance, we transformed exchanges of actual mail, and changed the enunciation form from "the Tour" to "I". Invited by the cultural institution, we organised and performed a visit of the Tour Utrillo as if she were telling her memories on a special day, her fortieth birthday party, a couple of months before her destruction (Fig. 3). The public (two groups of 25-30 people) was invited to climb the thirteen floors, plunged into darkness, as there has been no electricity for years. On the top floor, we were waiting for them, with a birthday cake, and started to tell the story of the Tour that we had written, as if she were talking. This performance triggered discussions about the Tour, these suburbs, the place. New facts and information were told, as if all stories and all investigations are never ending. 


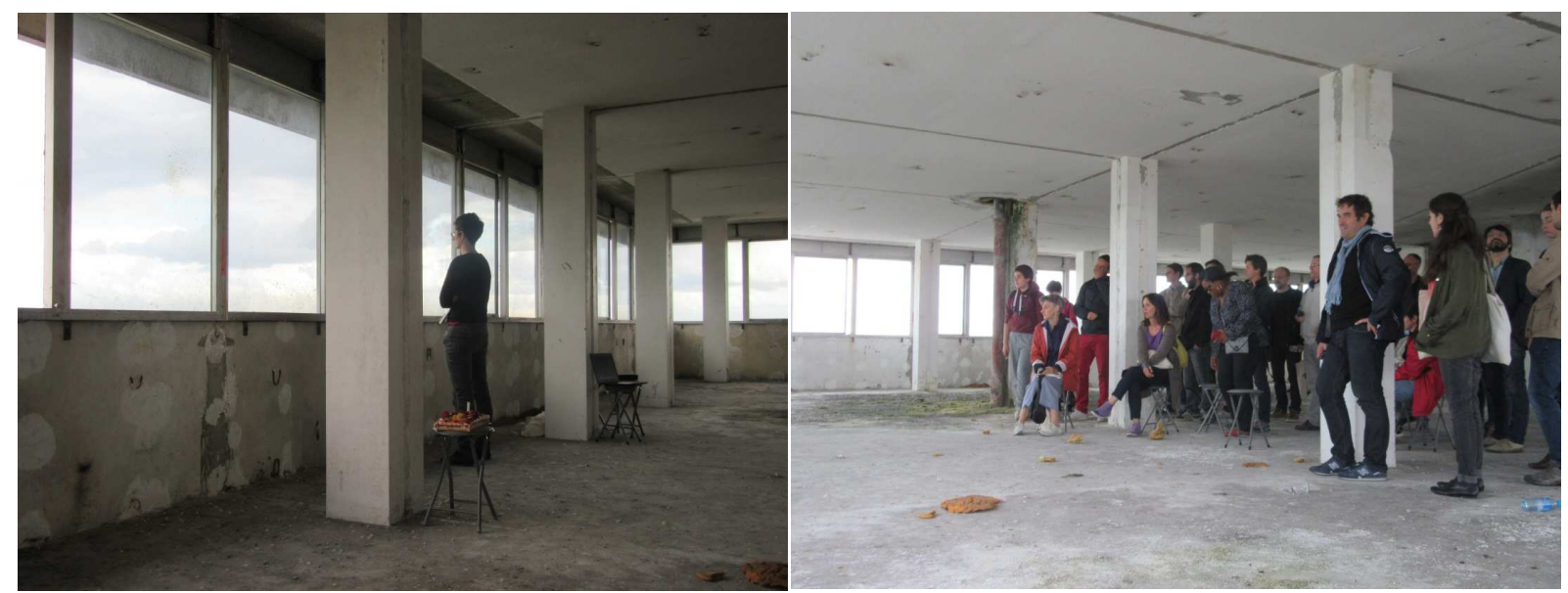

Fig. 3. Performing research results: the visit of the Tour Utrillo on her $40^{\text {th }}$ birthday

Writing the analysis of the history of public intervention on the Tour Utrillo from the point of view of the building itself, as a character, afforded an understanding of public policy as a lifelong process, from the birth and childhood, to the youth, maturation and then decline, dereliction and demolition of the Tour and the neighbourhood. This also focuses attention on details that usually seem anecdotal in a research process but which, here, become more meaningful ${ }^{4}$.

\section{To experience the distances and memories}

Another way to get round the effect of saturation of knowledge was to consider the personal experiences and perceptions of the place, so as to shed light on the making of this public space. This enabled us to understand the sense of involvement and attachment of those who live and work there (and our own). First, we (the group of artists and researchers) walked from the very centre of Paris (the Ministry of Culture) to the future location of the cultural institution (about 27 kilometre). This was a way to experience the geographic and social distances between the centre of power and these two towns, presented by some authors as the banlieue of the Republic, which etymologically means ban-lieu: the place out of the city, excluded from the city (Kepel, 2012). This was not the first time each of us went there, but it was the first time that this space became our field of investigation, and it was our first experience of the field together. That seven-hour visit was above all a way of becoming acquainted, of testing everyone's prejudices, of discussing the purpose of our project, and of witnessing the appearance of the first tensions. The two voices tale of this walk is one chapter of the newspaper L'Ouvroir.

Walking is a fieldwork method of observation and perception for both artists (O'Rourke, 2013) and social scientists (Grosjean \& Thibaud, 2008; Limb \& Dwyer, 2001 ), with different

\footnotetext{
${ }^{4}$ For instance, in the early '90s, when the Tour Utrillo was fifteen years old, a popular French businessman and politician, Bernard Tapie, had his heart set on it, and promised businesses and jobs. Why he went there is still mysterious, but the fact that he did has lingered in local memories even though it had no convincing effect on local economic development. This event takes on new meaning if we consider his controversial biography and especially his experience as a singer. One of his songs, Reussir sa vie (Succeed in life), sounds like a metaphor of dreams and expectations of economic development policies. More than simply being mildly amusing, it helps to understand Tapie's power of seduction, like an appealing bad boy facing young inexperienced administrations.
} 
protocols. According to Bossé (2015), the visit produced a shared experience of the space, during which the visitor reconstructs the actual meaning of the visit and of the space visited. The experience of the visit transforms both the visitor and his or her perception of the space. Indeed, this walk stimulated memories, the memory of my first personal visit there, years ago, before the urban renewal. I did not recognize a single thing and I felt lost. Yet this memory is still the lens through which I analysed what I observed. Influenced by the work of Despret and Meuret on the learning process of shepherds trained by the sheep themselves (Despret \& Meuret, 2016), we supposed that the first experience of the place influences the way people think, act, work and live there. In some ways, the account of the first time reveals how urban professionals are trained by the place itself. So, one main direction of the research was to ask interviewees about their memories of their first visit there: can you tell me about the first time you came here? This question reveals how people (as inhabitants or professionals) relate to the place, and turns out to be a great starter for an interview. It elicited various narratives of the place, from those who remembered the early years of the newly-built neighbourhood (as a clean, quiet and peaceful place), the newcomers, who knew only the renewed area, and those who remembered the dereliction resembling a war zone (someone referred to Sarajevo and the Yugoslavian war). These accounts actually describe the changes of the urban landscape during the past fifty years. Considering the memories and the professional positions of interviewees, we can also understand how the first visit acts and drives meanings of professional involvement in the place. We performed excerpts from the first-time interviews to the audience, who was invited to lie down on the floor and to close their eyes and listen. The performance revived memories for some of them, who then wished to tell about their own first time at Clichy-Montfermeil. Here the performance of the data collected contributed to the collection of new data.

\section{To develop conventional means and frameworks}

Telling the story of this collaboration afterwards should not hide the difficulties we faced in the collaboration process. The first but not least was to get organised. Because each of us had other activities or even a full-time job, it was difficult to make time together. For instance, it took one month to organise our first activity, the walk from Paris to Clichy. We used online collaborative tools to make up for the lack of meetings and to share data. But this was soon insufficient, given the abundance of material. This organisational issue is probably the source of a feeling of incompletion.

Then, as Becker explains (Becker, 1982), to understand the collective process of (art) production, such collaboration between artist and social scientist requires the sharing of various conventional means to understand each other and agree on the direction we take, the questions we are asked, the artwork or presentation we want to create, the sense of authorship and the level of personal involvement in the project. Coming from different professional backgrounds (urban planning and social sciences research, geography, theatre, cinema and visual art), each of us brings the conventions of his or her own world to the group. Attending research seminars and plays, and exchanging books and thoughts were the first steps of the process that led to us build and share a common aesthetical, theoretical and methodological 
framework. For instance, working with a filmmaker on an incomplete film, I learnt how editing rushes appears to be a process of sense making as much as the text is. Aesthetic choices, like off screens, convey meaning. But the editing is also guided by technical constraints (sound quality) and the availability of scenes (how can elements that have not been filmed, be integrated)? Hence, the filming of a documentary implies reflection prior to the scenes to be filmed. The intention precedes the filming, which modifies the intention. A second way of stabilising our conventional framework was to design some prototypes. As explained above, the means of representation was not defined a priori; it was negotiated between us through the prototypes that also revealed the plurality of points of view within the team. The first one was a fanzine that edited some traces of our walk: the list of streets, cognitive maps, soundcloud, herbarium, etc. Another one was a performance during which some texts, related to the various subjects of our investigation, were read anonymously and randomly. At the same time, someone was digging a hole in the garden, as a metaphor of the upcoming construction work on the underground metro station. Prototypes, as a boundary object (Star, 2010), helped to set our framework and objectives: to design an artwork as a narrative of complexity and plurality of voices and points of view that organises our material into episodes.

The creation of the prototype revealed points of disagreement. Initially there were five people in the group, and two other visual artists joined us during the first step of the research. Divergences soon appeared: about the understanding of the issue we wanted to address, the methodologies we implemented, the political meaning of our work, and the analysis we made of the field. My position in the group made it difficult to objectively analyse what led to the separation. Based on my notes taken during the meeting (especially on the production of prototypes) and on email correspondence, I noted that several misunderstandings and differences in the modalities and meaning of work were constantly present. For some, the idea was to build a narrative on the complexity by employing and transforming the material collected during the inquiry. Others focused more on actions with a performative value, justified by their "exciting" (sic) nature more than their search for meaning, like for example digging a hole on the spot of the future station, going to Rome to inquire about the historical Villa Medici, or asking the residents to imitate the sound of pigeons. It was with the latter proposition that the break was made. Regarding the intentions behind my decision to participate in this experiment (observing collaboration between artists and social scientists), I was reluctant to endorse this scission. But tensions within the group were such that I was resolved to proceed. My position in the group, as both participant and observer, was also criticised - and rightly so - insofar as it gave the others the unpleasant impression of being like guinea pigs under the observer's microscope. This dispute is a reminder of the difficulties of collaboration and making of convention (Arab, et al., 2016). Collaboration of this nature involves not only methods, references, theories and their hybridisations; it is above all an encounter between singular individuals, their subjectivity, their fears, and their convictions, shaped through their personal and professional pathways. Note however that the three participants in the experience share, to some degree, a position of the marginal secant (influential outsider) between the worlds of art and academia (social science degrees and 
involvement in a professional or semi-professional artistic activity), and experiences within public institutions in working-class areas. These biographic proximities probably facilitated the creation of shared conventions. This may also explain why the input of each one is difficult to distinguish as we all contribute together to the design of activities. Then, time pressure and availability explain the difference of involvement in their implementation.

\section{Conclusion: limits and perspectives}

As an embedded social scientist in a creative process, I explored and enjoyed new ways of doing research, with particular attention to tiny details, to emotions and to the means of representation. More than just a sense of freedom, like other social scientists, I also testify to the heuristic value of such collaboration (Mazeau, 2015) and writing processes (Jablonka, 2014). But, like Elisabeth Pasquier, investigating the Nantes-Pornic suburban train (in reference to (Maspero, 1990)) (Pasquier, 2014), I was sometimes wandering if I was in the right place, as this approach failed to match the academic standards of writing and publishing. How can one know? Perhaps by listening to the reactions of the commissioner who assesses the various productions (fanzine, soundcloud, performances, newspaper) in relation to the question that he asks himself and us: to what extent does the creation of cultural institution contribute to the creation of a public space? During the discussions (recorded and transcribed) that followed the presentations, their appreciation was expressed in two respects. First, emotional: the putting into perspective of the various accounts of the first times at Clichy, for example, "create what's generic, universal" (sic); "it's very disturbing, it really moves me" (sic). This protocol was moreover taken up by the institution, for resident artists who were also questioned on their "first time" at Clichy. Some writings, like the saturated poem, were appreciated for their sensible qualities: "it's wonderful" (sic). This one is reused by another artist in his own project. As regards the meaning, the most interesting point (or at least the most surprising one), to my mind, was the effect produced by the juxtaposition of forms and texts. One of the commissioners, taking up the codes of film analyses, argued that random narration yields meaning: what he called the Kouletchov effect. "What's fascinating, is how one is able to create a flash of meaning by bringing together certain elements, without needing to say any more; it's a critical reading of all the public policies that have been implemented in this area that we find fascinating." (sic)

These works, investigations and representations contributed to moving forward with the issues that arose initially.

Our intention was to contribute to the making of a public for the research (and through the research). The production of a newspaper was intended to gain a large audience, as newspapers could be distributed freely in the public space. The commissioner disagreed with our proposal. According to him: "what one puts into the public space, even if the idea is very interesting to subvert this form of what's put in the public space, there's the side: I take it, I scan through it, I look at the pictures. There's above all a lot of text that's really interesting to read, yet at the same time, one does need a little background knowledge to read it. For a form to be received, it has to be presented in a way that's receivable. If we put things out in the public space without taking any risk, nothing would happen. It would be lost among the 
mounds of other stuff, because there's paper everywhere. Paper serves no purpose other than peeling potatoes. At some point, it also saturates the space"[sic]. The commissioner wished to organise meetings and mediation, both with groups of students and in community centres. This did not happen however, mainly due to the lack of time. The thousand copies of the newspaper had been distributed to the institutional partners, visitors and artists in residence. The only mediated activity was the visit of the Tour Utrillo for its $40^{\text {th }}$ birthday.

This experience had influenced my practices of research and writing. It led me to pay close attention and to perceive tiny or unexpected details and facts in the investigation process, and to imagine new forms of representation of my research, adapted to a larger audience. On the invitation of Les Ateliers Médicis, I am currently pursuing one of our unexplored ideas, considering the use of fiction in investigation and writing. More than a hybridization of methods, artist-researcher collaboration is an encounter between singular individuals and ways of thinking that mutually enrich each other. Embarking on this type of experience is by no means insignificant, and requires that we agree to shift positions, to recognise a part of ourselves in the other person's words, to be touched by an office block destined for demolition, and to leave space for the off-screen.

\section{Bibliography}

Agence Nationale pour la Rénovation Urbaine. (2004). Convention partenariale pour la mise en oeuvre du projet de rénovation urbaine de Clichy-sous-bois Montfermeil. In: ANRU.

Arab, N., Ozdirlik, B., \& Vivant, E. (2016). Expérimenter l'intervention artistique en urbanisme. Rennes: Presses Universitaires de Rennes.

Ardenne, P. (2002). Un art contextuel - Création artistique en milieu urbain, en situation, d'intervention, de participation. Paris: Flamarion.

Armagnague, M., Cossée, C., Cossée-Cruz, E., Hieronimy, S., \& Lallouette, N. (2017). Combiner sociologie et arts dans le receuil des données. Migrations et sociétés, 63-76.

Atelier Parisien d'Urbanisme, \& Observatoire des quartiers de gare du Grand Paris. (2015). Monographie du quartier de gare Clichy - Montfermeil. Paris: Apur, SGP, DRIEA.

Baqué, D. (2004). Pour un nouvel art politique. De l'art contemporain au documentaire. Paris: Flammarion.

Becker, H. S. (1982). Les mondes de l'art. Paris: Flammarion.

Becker, H. S. (2009). Comment parler de la société. Artistes, écrivains, chercheurs et représentations sociales. Paris: La Découverte.

Boren, T., \& Young, C. (2013). Getting Creative with the "Creative City"? Towards New Perspectives on Creativity in Urban Policy. International Journal of Urban and Regional Research, 37, 1799-1815.

Bossé, A. (2015). La visite. Une expérience spatiale. Rennes: Presses Universitaires de Rennes.

Breux, S., Collin, J.-P., \& Gringras, C. (2014). Représenter l'urbain : apports et méthodes. Québec: Presses de l'Université Laval.

Callon, M., Lascoumes, P., \& Barthe, Y. (2001). Agir dans un monde incertain. Essai sur la démocratie technique. Paris: Seuil.

Collectif. (2006). Clichy sans Cliché. Paris: Delpire editeur.

Collectif. (2008). Des nouvelles de la banlieue. Paris: Textuel.

de Kerangal, M. (2010). Naissance d'un pont. Paris: Verticales. 
Despret, V., \& Meuret, M. (2016). Composer avec les moutons - Lorsque les brebis apprennent à leurs bergers à leur apprendre. Avignon: Cardère.

Dewey, J. (2010). Le public et ses problèmes. Paris: Gallimard.

Dilain, C. (2006). Chronique d'une proche banlieue. Paris: Stock.

Fourmentraux, J.-P. (2008). Oeuvrer en commun. Dilemmes de la création interdisciplinaire négociée. Négociations, 25-39.

Goldsmith, K. (2011). Uncreative Writing. New York: Columbia University Press.

Grosjean, M., \& Thibaud, J.-P. (2008). L'espace urbain en méthodes. Marseille: Editions Parenthèses.

Habouzit, R., 2017. La copropriété dégradée, le relogement et après ? Professionnels et habitants dans une opération rénovation urbaine. $\mathrm{PhD}$ Thesis in Sociology, Université Paris Saclay.

Jablonka, I. (2014). L'histoire est une littérature contemporaine : manifeste pour les sciences sociales Paris: Seuil.

Kepel, G. (2012). Banlieue de la République. Société, politique et religion à Clichy sous bois et Montfermeil. Paris: Gallimard.

Latour, B., \& Woolgar, S. (2006). La vie de laboratoire. La production des faits scientifiques. Paris: La découverte.

Le Garrec, S. (2014). Les copropriétés en difficulté dans les grands ensembles. Le cas de Clichy-Montfermeil. Espaces et Sociétés, 53-68.

Lebard, J., \& Makooi, B. (2015). Une année à Clichy. La ville qui rêvait qu'on l'oublie. Paris: Stock.

Leibovici, F. \& Pihet, V., 2011. «Pour une école des arts politiques?» Tracés. Revue de Sciences humaines, Hors série: A quoi servent les sciences humaines? ([en ligne] http://traces.revues.org/5286).

Lelevrier, C. (2013). Forced relocation in France: How residential trajectories affect individual experiences. Housing Studies, 28, 253-271.

Limb, M., \& Dwyer, C. (2001). Qualitative methodologies for geographers. London: Arnold Publishers.

Maspero, F. (1990). Les passagers du Roissy-Express. Paris: Seuil.

Mazeau, G. (2015). Histoire sensible. Une expérience critique entre théâtre et histoire. Ecrire l'histoire, 253-257.

Mekdjian, S., Amilhat Szary, A.-L., Moreau, M., Nasruddin, G., Mabeye Deme, Houbey, L., \& Guillemin, C. (2014). Figurer les entre-deux migratoires. pratiques cartographiques expérimentales entre chercheurs, artistes et voyageurs. Carnets de géographes, http://www.carnetsdegeographes.org/carnets_terrain/terrain_07_01_Mekdjian.php.

Miles, M. (2005). Interruptions: Testing the Rhetoric of Culturaly Led Urban Development. Urban Studies, 42, 889-911.

Mitterrand, F. (2013). La récréation. Paris: Robert Laffont.

Molina, G. (2016). La fabrique littéraire des territoires : quand l'Oulipo renouvelle les pratiques de l'aménagement urbain. Territoire en mouvement.

Motte, W. (1986). Oulipo: a Primer of Potential Literature. Lincoln: University of Nebraska Press.

Moreau, M. (2015). A quoi sert la Villa Médicis? Dans les coulisses d'une institution à bout de souffle. Le Crieur, 22-37.

O'Rourke, K. (2013). Walking and Mapping. Artists as Cartographers. Cambridge: MIT Press.

Pasquier, E. (2014). La passagère du TER. Nantes: Rapport de recherche PUCA "du périurbain à l'urbain", LAUA - Ecole d'Architecture de Nantes.

Phillips, R. (2016). Georges Perec's experimental fieldwork; Perequain fieldwork. Social and Cultural Geography, (in print). 
Radovic, D. (2016). Measuring the non-measurable: On mapping subjectivities in urban research. City, Culture and Society, 7, 17-24.

Rancière, J. (2000). Le partage du sensible. Esthétique et politique. Paris: La Fabrique.

Rancière, J. (2008). Le spectateur émancipé. Paris: La Fabrique.

Ruffel, L. (2016). Brouhaha. Les mondes du contemporain. Paris: Verdier.

Star, S. L. (2010). Ceci n'est pas un objet-frontière! Réflexions sur l'origine d'un concept. Revue d'anthropologie des connaissances, 4, 18-35.

Terzi, C., \& Tonnelat, S. (2017). The publicization of public space. Environment and Planning A, 49, 519-536.

Till, K. E. (2011). Interim Use at a Former Death Strip? Art, Politics and Urbanism at Skulpturenpark Berlin_Zentrum. In M. Silberman (Ed.), The German Wall. Fallout in Europe (pp. 99-122). London: Palgrave Macmillan.

Tonnelat, S., \& Shankland, S. (2016). L'art en chantier. Paris: Archibooks.

Toussaint, J.-Y., \& Zimmermann, M. (2001). User, observer, programmer et fabriquer l'espace public. Lausanne: Presses Polytechniques et Universitaires Romanes.

Ville Ouverte. (2015). Paroles de Clichois. Rapport pour la ville de Clichy. 